\title{
Molecular Heterogeneity of Mouse Duodenal Alkaline Phosphatase
}

\author{
ASSOCIATION OF LIPIDS AND PEPTIDES
}

\author{
By P. R. V. NAYUDU and FRASER B. HERCUS \\ Department of Zoology, Monash University, Clayton, Vic. 3168, Australia
}

(Received 30 January 1974)

\begin{abstract}
Polyacrylamide-gel electrophoresis and Bio-Gel P-300 molecular-sieve chromatography of mouse duodenal alkaline phosphatase demonstrates its molecular heterogeneity, which, in a kinetic sense, is manifest also in the differential relative velocities of the heterogeneous forms of the enzyme with two substrates, phenylphosphate and $\beta$-glycerophosphate. Different treatments that eliminate most of the electrophoretic and chromatographic variability of the enzyme also decrease the velocities with both substrates so that the molar ratio of hydrolysis of one substrate relative to the other is also altered to a low but stable value. Concomitant with these changes, lipids and peptides are dissociated from the enzyme. The lipids are tentatively identified as a sterol and phospholipids. The peptides have an average composition of four to six amino acids and appear to be strongly electropositive. The conditions of dissociation suggest that their binding to the enzyme is non-covalent and predominantly based on hydrophobic and ionic bonding. The concept of lipid and peptide association would suggest prima facie differential molecular weights as a factor in the observed electrophoretic and chromatographic heterogeneity. However, the molecular forms of the enzyme with differences in elution volume equivalent to more than one-half the void volume of the Bio-Gel P-300 column, or even enzyme fractions dissociated from the lipids and peptides compared with undissociated portions, do not show any differences in sedimentation on sucrese-density-gradient centrifugation. This may be because the alterations in molecular weight owing to binding of small molecules are too small to be detected by this method. Alternatively, since lipids are involved, the binding may alter the partial specific volume in such a way that the buoyant density is not significantly altered.
\end{abstract}

Several types of modification of enzyme structure or conformation cause molecular heterogeneity, usually with resultant variability in function, owing to changes in the enzyme's substrate-binding properties and other reaction kinetics. With alkaline phosphatase (EC 3.1.3.1), multiple molecular forms of the human intestinal enzyme, separated by electrophoresis or DEAE-Sephadex chromatography, did not show any differences in $K_{m}, \mathrm{pH}$ optima or activation by $\mathrm{Mg}^{2+}$ ions when a single substrate was used (Moss \& King, 1962; Moss, 1963). However, molecular heterogeneity of mouse duodenal enzyme, demonstrated with both electrophoresis and anionexchange chromatography, was correlated with differences in relative velocities with phenylphosphate and $\beta$-glycerophosphate as substrates. Besides, those molecular forms with higher ratios of hydrolysis of phenylphosphate/ $\beta$-glycerophosphate also had higher $K_{m}$ values for the former substrate (Moog et al., 1966; Etzler \& Moog, 1968). Whereas the heterogeneity of alkaline phosphatase from various organs in different species of animals is adequately established (Wilkinson, 1970), the basis of the polydispersity of many enzymes of this group is not clearly elucidated.
Decrease in anodal electrophoretic migration of component forms of the enzyme from bone, liver and placenta as a consequence of neuraminidase treatment has led to the postulation of covalently bonded sialic acid groups as the cause of heterogeneity in some alkaline phosphatases. The intestinal enzymes of both rat and man are, however, not affected by neuraminidase treatment (Robson \& Harris, 1966; Rosen, 1967; Moss et al., 1967). Another type of modification causing heterogeneity is the formation of enzyme-lipid complexes postulated for human intestinal phosphatase (Keiding, 1964). Consistent with this concept is the statement by Moss $(1962,1963)$ that each organ probably elaborates a single alkaline phosphatase which undergoes slight structural changes and that the observed electrophoretic differences may be due to variation in charge rather than molecular size. In a comparable assessment with mouse duodenal phosphatase, Etzler \& Moog (1968) suggested that a process of transformation produces the molecular heterogeneity of this enzyme bound to the membrane of the microvilli, as the epithelial cells migrate to the tip of the villus. The results in the present paper show 
that treatments which cause dissociation of small molecules (lipids and peptides) from purified enzyme preparations, eliminate much if not most of the electrophoretic and chromatographic variability and leave a form of the enzyme with not only lowered activity but also altered relative velocities in hydrolysing phenylphosphate and $\beta$-glycerophosphate. Both the heterogeneity and the differential kinetics of the molecular forms seem to derive from structural or conformational changes brought about by the firm association of the lipids and peptides to a single enzyme. The apparently non-covalent nature of the binding constitutes yet another mode of origin of molecular heterogeneity of an enzyme.

\section{Materials and Methods}

\section{Enzyme purification, chromatography and assay}

Mice of SWR/s strain (Jackson Laboratories, Bar Harbor, Maine, U.S.A.) were killed at 3 weeks of age and duodenal segments of $6 \mathrm{~cm}$ length from the junction of the common bile duct were obtained, slit open longitudinally and the epithelial cells scraped off the mucosal surface after rinsing with cold saline $\left(0.9 \%, w / v ; 4^{\circ} \mathrm{C}\right)$. Subsequent operations were carried out at $4^{\circ} \mathrm{C}$. Pooled samples of the cells were homogenized in distilled water at a tissue concentration of $10 \%(w / v)$. The membrane-bound enzyme was solubilized with 2-methylpropan-1-ol by the method of Morton (1954) and the aqueous phase was dialysed against water overnight and centrifuged at $30000 \mathrm{~g}$ for $30 \mathrm{~min}$ to remove precipitated material. The supernatant was then subjected to fractional precipitation and the precipitate obtained by centrifugation when the acetone concentration was raised from 65 to $75 \%(\mathrm{v} / \mathrm{v})$ was redissolved in water. The enzyme was further purified by precipitation with ethanol in the range $65-75 \%(v / v)$ and the recovered enzyme dialysed against $0.05 \mathrm{M}$-sodium acetate adjusted to pH7.2 with acetic acid. The resultant enzyme preparation was spun at $30000 \mathrm{~g}$ for $30 \mathrm{~min}$ to remove insoluble material and applied to a column bed $(85 \mathrm{~cm} \times$ $2.5 \mathrm{~cm}$ ) of Bio-Gel P-300 (Calbiochem Ltd., Carlingford, N.S.W., Australia) set up according to manufacturer's instructions. Elution was carried out with the same solution and fractions of $10 \mathrm{ml}$ were collected. The methods of assay both with disodium phenylphosphate and disodium $\beta$-glycerophosphate have been described previously (Moog et al., 1966) and protein determinations were made by the method of Lowry et al. (1951), with bovine serum albumin as standard.

\section{Electrophoresis}

Polyacrylamide-gel electrophoresis was carried out in slab gels of linear concentration gradient $5-25 \%$ $(w / v)$. The Gradipore gels and the vertical electrophoresis apparatus manufactured to the specifications of Margolis \& Kenrick (1968) were purchased from Townson and Mercer Ltd., Blackburn, Vic., Australia. Samples applied to the gel by using sample spacers contained $2 \mathrm{M}$-sucrose and a trace of Bromophenol Blue. Electrophoresis was carried out at $4^{\circ} \mathrm{C}$ with a constant voltage of $15 \mathrm{~V} / \mathrm{cm}$ for $20 \mathrm{~h}$ in $0.07 \mathrm{M}$ Tris buffer adjusted to pH8.7 with $0.5 \mathrm{M}$-boric acid. The gel was removed from its glass casing, rinsed in water and stained for alkaline phosphatase activity by the azo-dye method (Pearse, 1968). The staining solution contained $0.001 \mathrm{M}-\mathrm{MgCl}_{2}, 0.125 \mathrm{M}$-sodium barbitone, and sodium $\beta$-naphthylphosphate and Diazo Blue B each at $0.05 \%(w / v)$. When the enzyme was recovered from the gel, the required zones, made visible by staining a strip of the gel, were homogenized and extracted with the gel buffer.

\section{Sucrose-density-gradient centrifugation}

Sucrose gradients of $5-20 \%(w / v)$ were set up in polypropylene centrifuge tubes with $0.05 \mathrm{M}$-sodium acetate solution, pH7.2, by the method described by Martin \& Ames (1961), at $4^{\circ} \mathrm{C}$. The sample of enzyme or marker protein $(100 \mu \mathrm{g}$ dissolved in $0.1 \mathrm{ml}$ of the same solution) was carefully layered on top of the gradient. The MSE automatic superspeed 50 centrifuge was prepared for the centrifugation and the gradients were placed in the $3 \times 3 \mathrm{ml}$ swing-out rotor precooled to $4^{\circ} \mathrm{C}$. The rotor was operated every time for $16 \mathrm{~h}$ at $120000 \mathrm{~g}\left(r_{\mathrm{av}} .7 .11 \mathrm{~cm}\right)$ with the temperature controlled thermostatically. Every enzyme fraction was individually subjected to sedimentation with each of the other enzyme samples investigated and the four marker proteins. At the end of the centrifugation, the sucrose gradient was fractionated with a MSE centrifuge-tube fractionator and 33 fractions were obtained for every sample. The individual fractions were either assayed for phosphatase activity or tested for marker proteins.

\section{Dissociation of lipids and peptides}

Fractions selected to represent predetermined $V_{\mathrm{e}}$ (elution volumes) from the Bio-Gel P-300 column were pooled from as many as six chromatographic elutions, dialysed and finally condensed by using an ultrafiltration cell (model 202, Amicon Corp., Lexington, Mass., U.S.A.) with a type PM-30 membrane which retains molecules of a minimal mol.wt. of $50 \times 10^{3}$. The enzyme preparations were dialysed again and centrifuged at $30000 \mathrm{~g}$ before being subjected to any of the following three methods of dissociation.

(1) Chloroform-methanol. The enzyme was precipitated from a clear aqueous solution with $40 \mathrm{vol}$. of chloroform-methanol $(2: 1, \mathrm{v} / \mathrm{v})$ at $4^{\circ} \mathrm{C}$ and the precipitate was separated by using a Gelman pressure filtration funnel (Gelman Instrument Co., Ann Arbor, Mich., U.S.A.) with an Alpha-6 Gelman 
membrane. The filtrate was evaporated under a stream of $\mathrm{N}_{2}$ and the dry residue was extracted three times with chloroform to remove the lipids and the insoluble peptides were subsequently dissolved in $80 \%(v / v)$ ethanol. The same method of chloroformmethanol precipitation was also used in the presence of $0.05 \mathrm{M}$-sodium acetate in the enzyme solution.

(2) Sodium dodecyl sulphate- $\left(\mathrm{NH}_{4}\right)_{2} \mathrm{SO}_{4}$. The enzyme solution was made $0.5 \%(\mathrm{w} / \mathrm{v})$ in sodium dodecyl sulphate at $4^{\circ} \mathrm{C}$ and precipitated by the addition of solid $\left(\mathrm{NH}_{4}\right)_{2} \mathrm{SO}_{4}$ to a concentration representing $70 \%(\mathrm{w} / \mathrm{v})$ saturation. The precipitated enzyme in half the sample was dialysed against water to recover the dissociated enzyme. The other half was extracted with $40 \mathrm{vol}$. of chloroform-methanol $(2: 1, v / v)$ and the supernatant was separated by centrifugation at $30000 \mathrm{~g}$ and evaporated to dryness under $\mathrm{N}_{2}$ to test for the presence of lipids and peptides.

(3) 2-Chloroethanol. Enzyme solutions were treated with 2-chloroethanol in different proportions, at three different temperatures $\left(4^{\circ}, 15^{\circ}\right.$ and $\left.38^{\circ} \mathrm{C}\right)$ for various times. Small molecules dissociated from the enzyme were separated either by precipitation of the protein with $80 \%(\mathrm{v} / \mathrm{v})$ ethanol, or by Sephadex LH20-molecular-sieve chromatography at $4^{\circ} \mathrm{C}$ with a column bed of $85 \mathrm{~cm} \times 2.5 \mathrm{~cm}$, by the method described by Zahler \& Wallach (1967). The eluting solvent was 2-chloroethanol-water $(1: 3, \mathrm{v} / \mathrm{v})$ instead of the 9:1 proportion used by Zahler \& Wallach (1967). The eluate was collected in $10 \mathrm{ml}$ fractions. The fractions were screened for alkaline phosphatase activity, proteins, peptides and lipids.

\section{Analysis of lipids and peptides}

Extracts of dissociated small molecules in chloroform-methanol $(2: 1, \mathrm{v} / \mathrm{v})$ or $80 \%(\mathrm{v} / \mathrm{v})$ ethanol and eluate fractions of the Sephadex LH-20 column were evaporated to dryness under $\mathrm{N}_{2}$ and the lipids and peptides were separated by extracting the residue with chloroform and $80 \%(\mathrm{v} / \mathrm{v})$ ethanol respectively.

(1) Fluorescamine assay. The highly sensitive 'Fluram Roche' reagent (Roche Products Ltd., Dee Why, N.S.W., Australia) for primary amines was used to screen the samples for peptides by the spectrofluorimetric assay described by Udenfriend et al. (1972). Pooled fractions or samples positive to the test were used for t.l.c. and amino acid analysis.

(2) Thin-layer chromatography. Commercially manufactured t.l.c. plastic sheets (silica-gel $F_{254}$, E. Merck, Darmstadt, Germany) were activated for $1 \mathrm{~h}$ at $100^{\circ} \mathrm{C}$ and the samples of lipids in chloroform and peptides in $80 \%(\mathrm{w} / \mathrm{v})$ ethanol were applied.

(a) The separation of peptides was carried out by the development of the thin-layer plate in $80 \%(\mathrm{v} / \mathrm{v})$ ethanol. When dry the plate was sprayed with $0.05 \%$ $(w / v)$ ninhydrin in acetone and heated for $20 \mathrm{~min}$ at $100^{\circ} \mathrm{C}$ to make the spots visible. (b) For the t.l.c. plates spotted with lipids, two solvent systems were used for development. For separation of lipids into classes (Freeman \& West, 1966) the plates were first developed in diethyl ether-benzene-ethanol-glacial acetic acid (20:25:1: 0.1 , by vol.) for two-thirds of the plate, air-dried and then developed in diethyl ether-hexane $(3: 47, \mathrm{v} / \mathrm{v})$ till the solvent front reached the top of the plate. The lipid spots were made visible by spraying with phosphomolybdic acid $(10 \%, \mathrm{w} / \mathrm{v})$ in ethanol and heating at $100^{\circ} \mathrm{C}$. The phospholipids that stayed at the origin were recovered from unstained plates, pooled and spotted on a fresh plate. A mixture of phospholipids freshly extracted from egg yolk (Bligh \& Dyer, 1959) was spotted as a control sample on the same plate, which was developed in the solvent mixture di-isobutyl ketone-glacial acetic acid-water $(80: 50: 7$, by vol.) (Nichols, 1964). The plate was dried and sprayed with a specific reagent for phosphatides (Vaskovsky \& Kostetsky, 1966), which on heating at $100^{\circ} \mathrm{C}$ for $20 \mathrm{~min}$ was seen as blue spots against a white background.

(3) Amino acid composition. Fractions of the Sephadex LH-20 column (nos. 30-45) representing the eluate between two and three void volumes of the column were pooled and evaporated to dryness under $\mathbf{N}_{2}$. The lipids were removed by the addition of chloroform. The residual peptides were separated on thin-layer plates. Unstained peptides from several spottings of the same sample on a plate were recovered by staining only one lane and extracting the scrapedoff silica gel from the others twice with $80 \%(v / v)$ ethanol. The pooled sample was dried and a measured portion of the dissolved peptide pool was assayed with fluorescamine. The rest of the sample was hydrolysed with $6 \mathrm{M}-\mathrm{HCl}$ at $105^{\circ} \mathrm{C}$ for $16 \mathrm{~h}$ in a sealed vial. After removing the acid by repeated addition of water and evaporation under $\mathbf{N}_{2}$, a measured portion was subjected to fluorescamine assay to determine the average number of amino acids in the mixture of peptides, and the rest of the sample was used for determination of the amino acid composition. The amino acid analysis was carried out with a JEOL automatic amino acid analyser, model JLC-6AH (Japan Electronic Optics Laboratory Ltd, Chigoda-Ku, Tokyo, Japan). The stationary phase was Jeol resin LC-R.2 and the mobile phase, sodium citrate, pH3.25, 4.25 and 5.28. The short column was $0.8 \mathrm{~cm} \times 11 \mathrm{~cm}$ with a column temperature of $52^{\circ} \mathrm{C}$ and the long column was $0.8 \mathrm{~cm} \times 65 \mathrm{~cm}$ with a temperature of $60^{\circ} \mathrm{C}$. For both the flow rate was $0.84 \mathrm{ml} / \mathrm{min}$.

\section{Results}

\section{Bio-Gel P-300 column chromatography}

The void volume was determined by the elution profile of Blue Dextran 2000 (Pharmacia, Uppsala, 


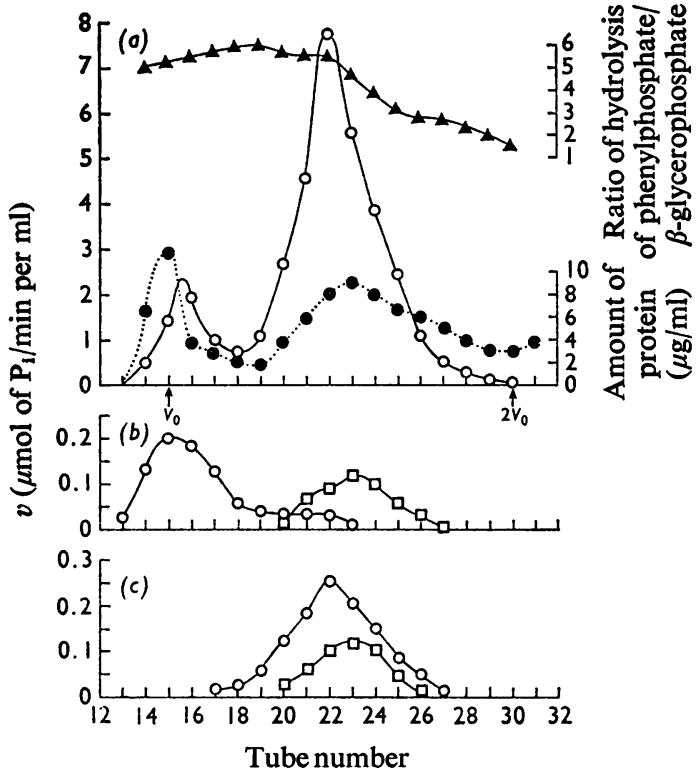

Fig. 1. Bio-Gel P-300 chromatography of partially purified enzyme and rechromatography of peak fractions before and after dissociation

(a) Enzyme ( $6 \mathrm{ml})$ purified by acetone and ethanol fractionation and containing $600 \mu \mathrm{g}$ of protein $/ \mathrm{ml}$ was applied to the column. Fractions $(10 \mathrm{ml})$ were collected. $O, v$ determined with $\beta$-glycerophosphate as substrate; $\Theta$, protein concentration; $\Delta$, molar ratio of hydrolysis of two substrates, phenylphosphate $/ \beta$-glycerophosphate. $V_{0}$, void volume. (b) Rechromatography of fraction no. 16 before $(O)$ and after ( $\square$ ) 2-chloroethanol dissociation of small molecules. (c) Rechromatography of fraction no. 22 before $(O)$ and after ( $\square$ ) 2-chloroethanol dissociation of small molecules.

Sweden). The enzyme preparation obtained by 2 methylpropan-1-ol solubilization followed by successive fractional precipitations with acetone and ethanol had an activity 80-100-fold higher per unit amount of protein as compared with the crude homogenate. Individual fractions representing the enzyme peaks eluted from the Bio-Gel column (Fig. 1) showed 300-400 times the enzyme activity of the crude homogenate $/ \mu \mathrm{g}$ of protein. The alkaline phosphatase was eluted in a large number of fractions with the first peak of activity coinciding with the void volume and the second larger peak at $1 \frac{1}{2}$ times the void volume. Fig. 1 also shows that the molar ratio of hydrolysis of phenylphosphate to $\beta$-glycerophosphate of individual fractions is variable and shows a distinct decrease in those that constitute the end of the second peak. When single fractions of the highest activity from the two peaks of enzyme activity were rechromatographed separately, there was no shift in the elution of enzyme other than the 'spread' caused by diffusion. However, when the fraction representing the first peak was treated with 2chloroethanol, the peak of eluted enzyme activity shifted to the position of the second peak. A similar treatment of the second peak enzyme did not alter the elution pattern. In both the first and second peak fractions the extraction with 2-chloroethanol caused perceptible lowering of activity associated with a decrease in the molar ratio of hydrolysis of phenylphosphate to $\beta$-glycerophosphate.

\section{Polyacrylamide-gel electrophoresis}

The characteristic feature of the enzyme subjected to electrophoresis in the $5-25 \%(\mathrm{w} / \mathrm{v})$ linear-gradient slab gel (Plate 1) is its heterogeneity. With the enzyme sample partially purified by ethanol and acetone fractional precipitation, the alkaline phosphatase molecules are present over a length of gel representing a $5-17 \%$ concentration gradient and the molar ratio of hydrolysis of phenylphosphate $/ \beta$-glycerophosphate is lower for the fast-migrating components (Plate 1a). Each of the three single fractions from the Bio-Gel P-300 column representing different volumes of elution shows considerable heterogeneity. Nevertheless, it is obvious that, over its entire range, the distance of electrophoretic migration is positively correlated with $V_{\mathrm{e}}$ from the column (Plate $1 b, c$ and $d$ ). Condensed and dialysed enzyme preparations from the main peak of the Bio-Gel column subjected to two different procedures to dissociate small molecules show a single zone of activity on the gel with very similar mobility, with almost an $80 \%$ decrease in heterogeneity (Plate $1 f$ and $g$ ). Similarly, fractions obtained at three different volumes of elution from the Bio-Gel column and extracted with 2-chloroethanol gave electrophoretically identical zones of residual enzyme activity on the gel (Plate $1 h, i$ and $j$ ).

\section{Sucrose-density-gradient centrifugation}

The results presented in Fig. 2 show that the enzyme fractions at different volumes of elution from the Bio-Gel P-300 column are indistinguishable in their sedimentation properties not only from each othei but also from split samples extracted with 2-chloroethanol. A difference of about $12 \times 10^{3}$ daltons wouls be required to cause the peak to shift by one fractiva and therefore the sensitivity of the system is such that molecular-weight changes of a smaller magnitude would not be detectable by this method. 


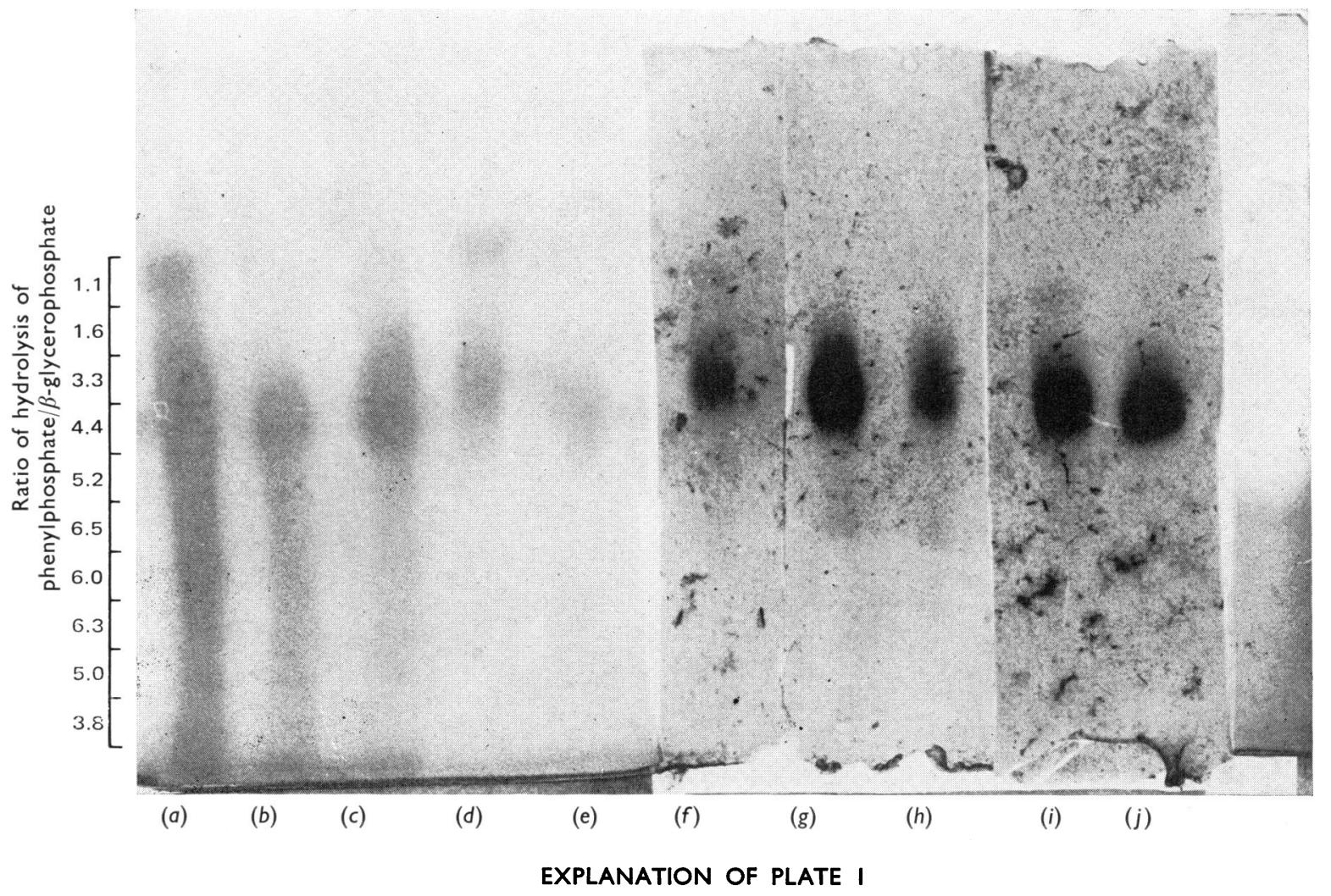

Polyacrylamide-gel electrophoresis of selected fractions from Bio-Gel P-300 column before and after dissociation

A portion $(50 \mu \mathrm{l})$ of each sample was applied with a sample separator. (a) Ethanol- and acetone-precipitated enzyme. The molar ratios of hydrolysis of the different zones were obtained by assaying enzyme extracted from sliced segments of another gel electrophoresed at the same time. $(b)-(d)$ Condensed individual fractions of Bio-Gel P-300 column eluate. $(b)$ No. 15; $(c)$ no. $22 ;(d)$ no. 26. (e) Enzyme as in $(a)$ but extracted with 40 vol. of chloroform-methanol $(2: 1, \mathrm{v} / \mathrm{v}) .(f)$ and $(g)$ Bio-Gel P-300 column fraction no. 22; $(f)$ extracted with $40 \mathrm{vol}$. of chloroform-methanol $(2: 1, \mathrm{v} / \mathrm{v})$, and $(\mathrm{g})$ precipitated with solid $\left(\mathrm{NH}_{4}\right)_{2} \mathrm{SO}_{4}$ after addition of sodium dodecyl sulphate $(0.5 \%, \mathrm{w} / \mathrm{v})$. (h)- $(j)$ Condensed individual fractions of Bio-Gel P-300 column extracted with $\frac{1}{3} \mathrm{vol}$. of 2 -chloroethanol at $15^{\circ} \mathrm{C}$ for $10 \mathrm{~h}$. (h) Fraction no. 15; (i) fraction no. $22 ;(j)$ fraction no. 26. 


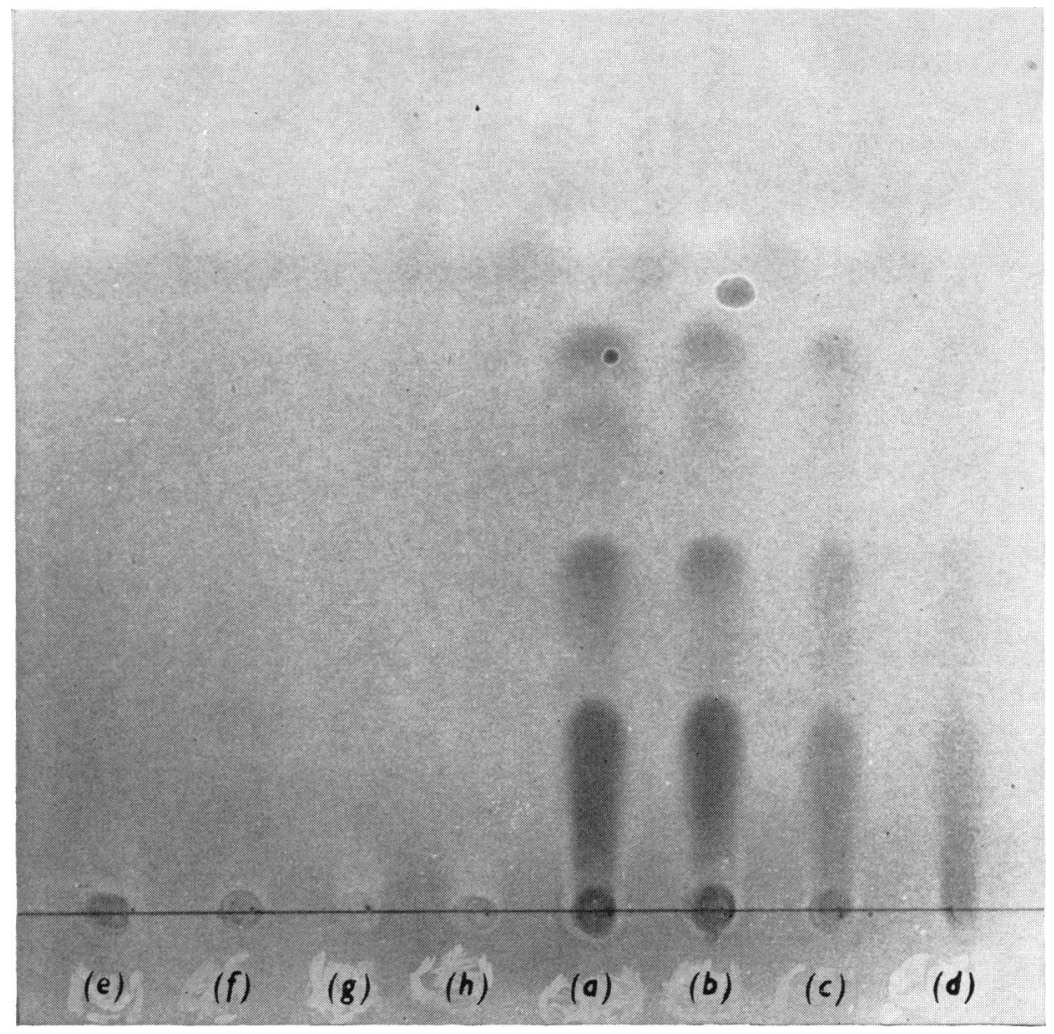

\section{EXPLANATION OF PLATE 2}

\section{T.l.c. of peptides dissociated from purified enzyme fractions}

Pooled enzyme fractions (each containing $100 \mu \mathrm{g}$ of protein) from Bio-Gel P-300 chromatography were dialysed and condensed. After the removal of any precipitated material, each sample was treated with $\frac{1}{4}$ vol. of 2 -chloroethanol at $38^{\circ} \mathrm{C}$ for $3 \mathrm{~h}$ and the protein precipitated with $80 \%(\mathrm{v} / \mathrm{v})$ ethanol. The supernatant was evaporated to dryness under $\mathrm{N}_{2}$ and the lipids removed by extraction with chloroform. The peptides were then dissolved in $80 \%(\mathrm{v} / \mathrm{v})$ ethanol and spotted on the thin-layer plate, developed in $80 \%(\mathrm{v} / \mathrm{v})$ ethanol and stained with ninhydrin. (a) Fraction no. 16; (b) fraction no. 20; $(c)$ fraction no. 23; $(d)$ fraction no. 26. The precipitated protein of each of the fractions $(a)-(d)$ was redissolved in water and the 2-chloroethanol treatment repeated. The supernatants after precipitation of the protein were used for t.l.c. in the same manner as described above. The second extractions of protein precipitates of $(a)-(d)$ respectively are spotted on $(e)-(h)$. The absence of peptides in these extracts shows that those from the first extraction were not due to protein breakdown. 


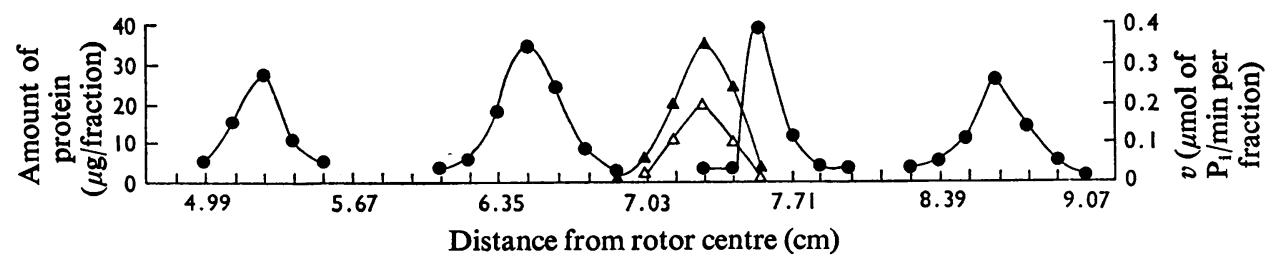

Fig. 2. Sucrose-density-gradient centrifugation of selected fractions from Bio-Gel P-300 column before and after dissociation

Sucrose gradients $(5-20 \%, \mathrm{w} / \mathrm{v})$ in polypropylene tubes, with samples layered on top, were centrifuged in a MSE Superspeed 50 centrifuge. The $3 \times 3 \mathrm{ml}$ swing-out rotor was operated for $16 \mathrm{~h}$ at $120000 \mathrm{~g}\left(r_{\mathrm{av}} .7 .11 \mathrm{~cm}\right)$. Sedimentation pattern of marker proteins (O) (lysozyme, bovine serum albumin, aldolase and catalase from left to right in that order). Sedimentation pattern of selected enzyme fractions of Bio-Gel P-300 column before $(\Delta)$ and after $(\Delta)$ dissociation of small molecules with 2-chloroethanol. Identical sedimentation patterns were obtained for tubes 15, 22 and 26.

Table 1. Effect on enzyme activity of treatments that dissociate small molecules

The relative activity of the untreated enzyme in arbitrary units is based on assays carried out under optimal conditions for each substrate. Portions of a bulk enzyme preparation were subjected to the different treatments indicated.

\begin{tabular}{|c|c|c|c|}
\hline \multirow[b]{2}{*}{ Treatment } & \multicolumn{2}{|c|}{ Relative activity } & \multirow{2}{*}{$\begin{array}{l}\text { Molar ratio of } \\
\text { hydrolysis of } \\
\text { phenylphosphate } / \beta \text { - } \\
\text { glycerophosphate }\end{array}$} \\
\hline & $+\beta$-glycerophosphate & + Phenylphosphate & \\
\hline None & 100 & 600 & 6.00 \\
\hline $\begin{array}{l}\text { Precipitation with } 40 \text { vol. of chloroform-methanol } \\
(2: 1, v / v) \text { at } 4^{\circ} \mathrm{C}\end{array}$ & 30 & 70 & 2.30 \\
\hline $\begin{array}{l}\text { Precipitation with } 40 \mathrm{vol} \text {. of chloroform-methanol } \\
(2: 1, \mathrm{v} / \mathrm{v}) \text { at } 4^{\circ} \mathrm{C} \text {, after making the enzyme soln. } \\
0.05 \mathrm{M} \text { in sodium acetate }\end{array}$ & 20 & 14 & 0.70 \\
\hline $\begin{array}{l}\text { Enzyme soln. made } 0.5 \%(\mathrm{w} / \mathrm{v}) \text { in sodium } \\
\text { dodecyl sulphate and then precipitated with } \\
4 \text { vol. of satd. }\left(\mathrm{NH}_{4}\right)_{2} \mathrm{SO}_{4} \text { soln. at } 4^{\circ} \mathrm{C} \\
+4 \text { vol. of } 2 \text {-chloroethanol }\end{array}$ & 30 & 23 & 0.75 \\
\hline (a) at $4^{\circ} \mathrm{C}$ for $20 \mathrm{~h}$ & 50 & 150 & 3.00 \\
\hline $\begin{array}{l}\text { (b) at } 15^{\circ} \mathrm{C} \text { for } 20 \mathrm{~h} \\
+ \text { Equal vol. of } 2 \text {-chloroethanol }\end{array}$ & 20 & 34 & 1.70 \\
\hline (a) at $4^{\circ} \mathrm{C}$ for $30 \mathrm{~min}$ & 40 & 100 & 2.50 \\
\hline (b) at $15^{\circ} \mathrm{C}$ for $30 \mathrm{~min}$ & 15 & 9 & 0.60 \\
\hline
\end{tabular}

\section{Dissociation of enzyme-bound molecules}

Three different experimental approaches were used and the results are presented in Table 1. With chloroform-methanol precipitation, the addition of sodium acetate resulted in a more efficient dissociation, resulting in lower residual activity and molar ratio of hydrolysis of phenylphosphate to $\beta$-glycerophosphate. The addition of 2-chloroethanol was the most useful method since gradual dissociation could be obtained because of its dependence on (i) the concentration of 2-chloroethanol (Table 1), (ii) temperature and (iii) the duration of extractions (Fig. 3). As the residual activity of the enzyme decreases, the molar ratio of hydrolysis of phenylphosphate to $\beta$-glycerophosphate also declines, indicating that the activity of the enzyme with the former substrate is more sensitive to the dissociation of the enzyme-bound molecules. Dissociation by any of the three methods resulted in a minimal residual enzyme activity of at least $15-20 \%$ and the lowest molar ratio of the two substrates was 0.6-0.7. Re-extraction of this enzyme resulted in total loss of activity, suggesting that a minimal association with the dissociated molecules may be necessary for the enzymic function.

\section{Identity of dissociated molecules}

(1) Peptides. The results of chromatography of an enzyme preparation treated with 2-chloroethanol on a Sephadex LH-20 column are presented in Fig. 4. The protein peak eluted with the void volume contains 


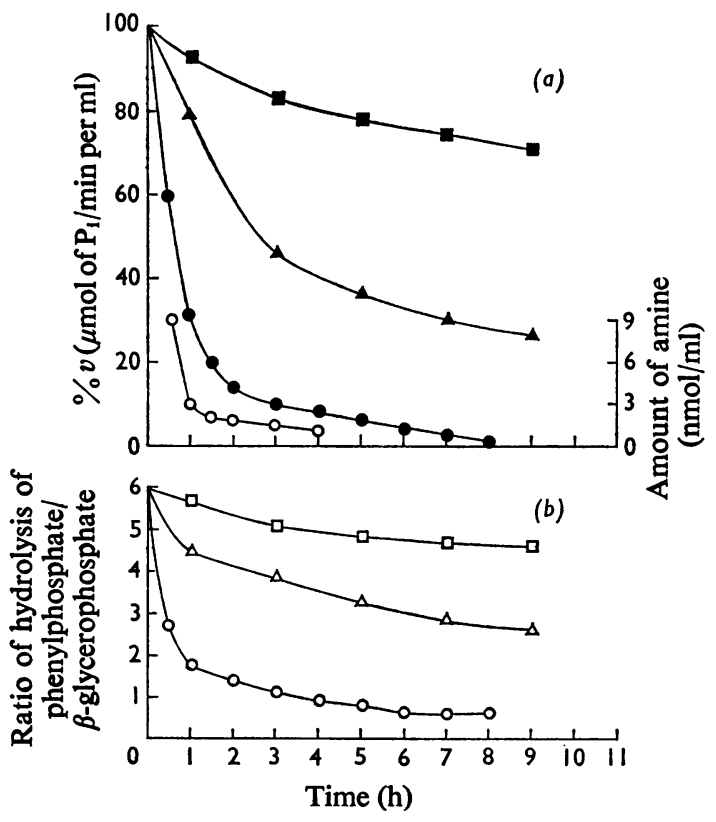

Fig. 3. Effect of temperature and duration on dissociation of small molecules with 2-chloroethanol

Split samples of enzymes solution mixed with $\frac{1}{4}$ vol. of 2-chloroethanol were left at $4^{\circ}, 15^{\circ}$ and $38^{\circ} \mathrm{C}$. Portions were obtained at time-intervals for phosphatase assay with both phenylphosphate and $\beta$-glycerophosphate. $v$ is expressed as percentage values of controls to which 2-chloroethanol was not added. (a) Activity with $\beta$ glycerophosphate: $\square, 4^{\circ} \mathrm{C} ; \Delta, 15^{\circ} \mathrm{C} ; 0,38^{\circ} \mathrm{C}$. Portions $(1 \mathrm{ml})$ were also taken from the $38^{\circ} \mathrm{C}$ sample and precipitated with $80 \%(\mathrm{v} / \mathrm{v})$ ethanol. The supernatant was evaporated to dryness under $\mathrm{N}_{2}$ and the peptides and amino-phospholipids were assayed with fluorescamine to estimate the dissociation of the small molecules in relation to lowering of activity and molar ratio of the two substrates. Amounts (nmol) of primary amines released by $1 \mathrm{ml}$ portions of enzyme are shown (O). (b) Decrease in the molar ratio of hydrolysis of phenylphosphate $/ \beta$ glycerophosphate. $\square, 4^{\circ} \mathrm{C} ; \triangle, 15^{\circ} \mathrm{C} ; 0,38^{\circ} \mathrm{C}$.

the enzyme with residual activity. The second peak of fluorescamine-positive material represents aminophospholipids and peptides dissociated from the enzyme molecules. Peptides from four separate pooled samples representing different volumes of elution from the Bio-Gel P-300 column were subjected to t.l.c. (Plate 2). There were no differences in either the number of peptides or their migration distances between the four samples. When the peptides were hydrolysed with $6 \mathrm{M}-\mathrm{HCl}$ at $105^{\circ} \mathrm{C}$ for $16 \mathrm{~h}$, they showed a four- to six-fold increase in amino groups determined by fluorescamine reagent, indicating an average of as many amino acids per peptide. A portion of acid-hydrolysed peptides derived from pooled fraction no. 22 of the Bio-Gel P-300 column gave the amino acid composition presented in Table 2. The following amino acids are not present: half-cystine, proline, methionine and tyrosine; and the dicarboxylic and neutral amino acids together constitute $90 \%$ of the total amino acids. However, there was an unusually large amount of $\mathrm{NH}_{3}$, which would suggest that all of the secondary carboxylic acid groups of aspartic acid and glutamic acid could have been amidated (Wallach \& Zahler, 1968). If so these peptides would be expected to carry net positive charges even at $\mathrm{pH}$ values on the alkaline side of neutrality. When these peptides were subjected to thin-layer electrophoresis (results not presented here) all the peptides migrated towards the cathode both at $\mathrm{pH} 6$ and 9.

(2) Lipids. The lipids eluted from the Sephadex LH-20 column in fractions $30-45$ were pooled and, after separating the peptides, subjected to t.l.c. for separation into classes. In Fig. 5(a) there are only two classes recognizable, namely phospholipids at the origin and a sterol. The sterol is indistinguishable from cholesterol with respect to its u.v. absorbance. The phospholipids separated (Figs. $5 b$ and $c$ ) from each other show four spots, one of which has the same $\boldsymbol{R}_{\boldsymbol{F}}$ value as egg-yolk sphingomyelin. The other three have mobilities greater than phosphatidylinositol, phosphatidylserine and phosphatidylethanolamine of egg yolk respectively. It is likely that these differences are due to variations in chain lengths and/ or double bonds in the fatty acids of the egg-yolk phospholipids relative to those extracted from the enzyme.

\section{Discussion}

Unequivocal evidence of heterogeneity is provided by both the molecular-sieve chromatography and electrophoretic data which demonstrate a continuum of molecular forms. The elution of the enzyme from the Bio-Gel column shows two peaks of activity, the $V_{\mathrm{e}}$ of the second differing from that of the first peak by $\frac{1}{2} V_{0}$ (void volume), suggesting distinct differences in molecular size. The electrophoretic heterogeneity seems more conspicuous with the enzyme molecules distributed over a concentration gradient of $5-17 \%$, a range representing an upper limit of molecular weight several times higher than the lower limit for spherical proteins used as standards in molecular-weight determination (Margolis \& Kenrick, 1968). The variation in molar ratios of hydrolysis of phenylphosphate and $\beta$-glycerophosphate by the different molecular forms show a comparable asymmetrical pattern in both the electrophoretic and chromatographic systems with the forms of enzyme having the lowest ratios behaving 


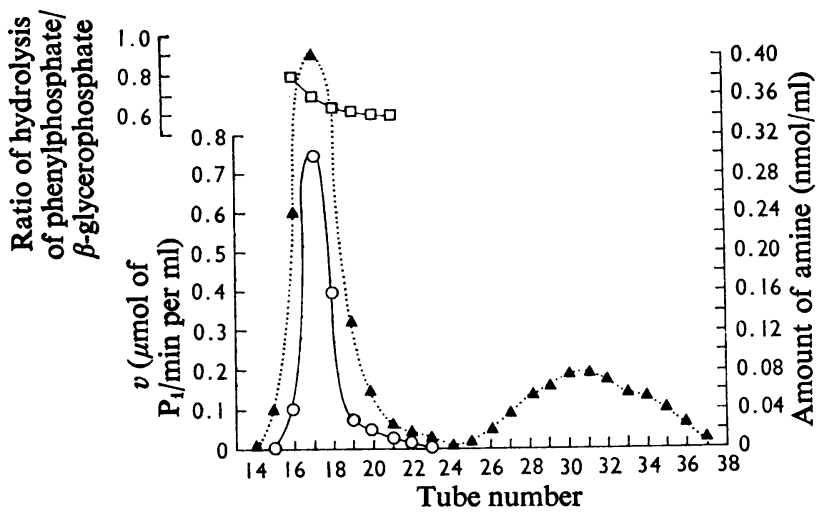

Fig. 4. Pattern of elution of dissociated enzyme and the fluorescamine-positive small molecules in Sephadex LH-20 chromatography

A pooled and condensed sample of fraction no. 22 from six chromatographic separations on Bio-Gel P-300 was dialysed and centrifuged at $30000 \mathrm{~g}$. The supernatant containing $500 \mu \mathrm{g}$ of protein was mixed with $\frac{1}{3}$ vol. of 2-chloroethanol, left at $15^{\circ} \mathrm{C}$ for $10 \mathrm{~h}$, at which time it had $25 \%$ of the original activity and the molar ratio of phenylphosphate/ $\beta$-glycerophosphate was 0.7 . The sample was applied to the column and eluted with 2-chloroethanolwater $(1: 3, v / v)$. The eluate was collected in $10 \mathrm{ml}$ fractions, which were evaporated under $N_{2}$. The dry residue was dissolved in water. Portions of each fraction were tested for (1) phosphatase activity with both phenylphosphate and $\beta$-glycerophosphate, and (2) primary amines with fluorescamine. $O$, Activity with $\beta$-glycerophosphate; $\square$, molar ratio of hydrolysis of phenylphosphate/ $\beta$-glycerophosphate; $\Lambda$, amount (nmol) of primary amines/ml of fraction.

\section{Table 2. Amino acid composition of peptides}

Fractions no. 22 from six successive Bio-Gel P-300 chromatographic experiments were pooled, condensed and dialysed. After dissociation with 2-chloroethanol, the peptides were separated on a Sephadex LH-20 column and hydrolysed with $6 \mathrm{M}-\mathrm{HCl}$ at $105^{\circ} \mathrm{C}$ for amino acid analysis.

$\begin{array}{cc}\text { Amino acid } & \begin{array}{c}\text { Amount } \\ (\mathrm{mol} / 100)\end{array} \\ \text { Lys } & 6.66 \\ \text { His } & 1.33 \\ \text { Arg } & 1.33 \\ \text { Asp } & 4.00 \\ \text { Glu } & 13.33 \\ \text { Thr } & 2.66 \\ \text { Ser } & 13.33 \\ \text { Gly } & 21.28 \\ \text { Ala } & 6.65 \\ \text { Val } & 2.66 \\ \text { Leu } & 2.66 \\ \text { Ile } & 1.33 \\ \text { Phe } & 1.33 \\ \text { NH } & 21.28\end{array}$

like 'smaller' and/or more negatively charged enzyme molecules. Similar differences of ratio and molecular heterogeneity of this enzyme were shown by Etzler \& Moog (1968) by anion-exchange chromatography and electrophoresis on starch gel.
Elimination of the electrophoretic and chromatographic heterogeneity is achieved by any of several methods, such as 2-chloroethanol treatment, $\left(\mathrm{NH}_{4}\right)_{2}$ $\mathrm{SO}_{4}$ precipitation of enzyme in the presence of sodium dodecyl sulphate, or chloroform-methanol extraction. The treated enzyme, whether obtained from the first or the second peak of the Bio-Gel column and irrespective of the method of extraction, gave a form of enzyme with similar residual activity, ratio of hydrolysis of the two substrates, $V_{\mathrm{e}}$ on the Bio-Gel column, and identical electrophoretic mobility. It would appear that this form represents a core enzyme with minimal association of small molecules. With 2-chloroethanol, the rate of lowering of activity and the molar ratio of hydrolysis of the two substrates were dependent on time, temperature and concentration and roughly proportional to the number of small molecules dissociated from the enzyme. This is the best evidence available for the relationship between binding of small molecules and activity. The small molecules appear to fall into two categories: (a) peptides, on an average composed of four to six amino acids; (b) lipids, tentatively identified as phospholipids and a sterol. However, the t.l.c. analysis of the peptides and lipids dissociated from enzyme preparations from different volumes of elution from the Bio-Gel column do not show any qualitative differences. The observed molecular 


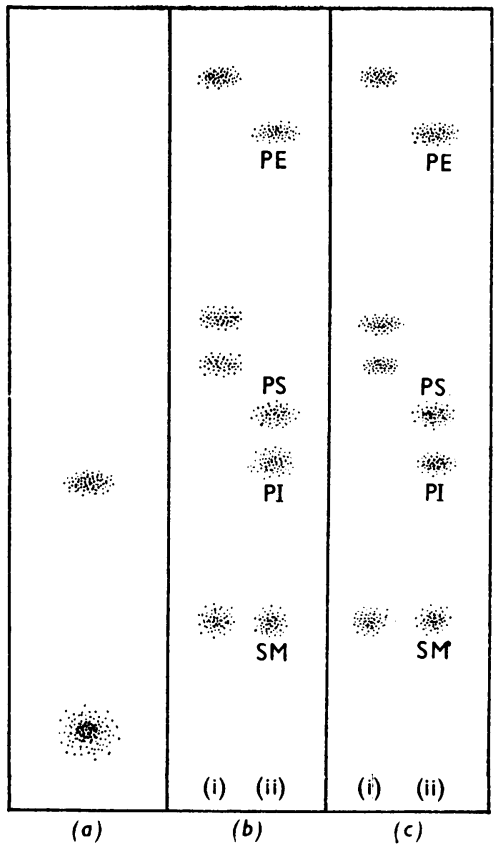

Fig. 5. T.l.c. of lipids dissociated from the enzyme

Lipids from pooled fractions (nos. 30-45) of a Sephadex LH-20 column were extracted with chloroform from the dry residue of the eluates evaporated to dryness under $\mathbf{N}_{2}$. The sample was spotted in 10 places on a thin-layer plate and developed in two solvents in succession (see the text) to separate the lipids into classes. (a) One of the 'lanes', stained with phosphomolybdic acid, shows phospholipids at the origin and another lipid, probably a sterol. (b) and (c) The phospholipids at the origin in the other nine lanes of the thin-layer plate above were scraped off the plate and recovered for spotting in lanes $b(\mathrm{i})$ and $c(\mathrm{i})$ on a thin-layer plate. Egg-yolk phospholipids were spotted in lanes $b$ (ii) and $c$ (ii). The plate was developed as described in the Materials and Methods section. (b) Stained with $10 \%$ (w/v) phosphomolybdic acid; (c) stained with specific reagent for phospholipids (see the text). SM, Sphingomyelin; PI, phosphatidylinositol; PS, phosphatidylserine; $\mathrm{PE}$, phosphatidylethanolamine.

heterogeneity may be based on differences in the amount of peptides and lipids bound to the enzyme molecules. Such an idea seems attractive because it would be consistent with possible molecular-weight differences between the multiple forms of enzyme molecules suggested by the chromatography and electrophoretic results. Alternatively, it is conceivable that the binding of the small molecules to different facets of the membrane-bound enzyme molecules may also produce the observed heterogeneity, with or without any quantitative differences in the numbers of small molecules bound to the enzyme molecule.

The small molecules bound to the enzyme are not dislodged either by 2-methylpropan-1-ol solubilization or by precipitation with acetone or ethanol, although the latter treatments are normally used to extract protein-bound lipids (Steck \& Fox, 1972). Their dissociation is only effected by 2-chloroethanol, chloroform-methanol precipitation or $\left(\mathrm{NH}_{4}\right)_{2} \mathrm{SO}_{4}$ precipitation in the presence of sodium dodecyl sulphate. 2-Chloroethanol, a strong solvent, promotes helical conformation of proteins and causes dissociation of protein-bound membrane lipids (Zahler \& Wallach, 1967) at an acidic pH, presumably by disruption of ionic and hydrophobic bonds between the proteins and lipids. Similarly, hydrophobic and ionic competition may be considered the two significant aspects in dissociation, mediated by sodium dodecyl sulphate and $\left(\mathrm{NH}_{4}\right)_{2} \mathrm{SO}_{4}$ (Rosenberg et al., 1969) or even chloroform-methanol in the presence of sodium acetate, between the enzyme molecules and the peptides and lipids. The inability of acetone or ethanol fractionation to cause dissociation may suggest that the non-covalent binding of the enzyme to the small molecules is very firm. Several unsuccessful attempts were made under varied conditions of $\mathrm{pH}$ and ionic concentration to reassociate the dissociated enzyme with the peptides and lipids. The failure of reassociation in vitro may be due to an altered conformation of the dissociated enzyme that does not permit a proper orientation for the rebinding of the small molecules.

In spite of the obvious suggestion of molecularweight differences as the basis of the heterogeneity, this idea is not unambiguously supported by the sucrose-density-gradient-centrifugation results. Enzyme samples irrespective of differences in $V_{\mathrm{e}}$ from the Bio-Gel column and split samples of dissociated enzymes showed indistinguishable sedimentation patterns. This would suggest that probably the differences in molecular weight between the molecular forms are smaller than the lower limit of about $12 \times 10^{3}$ daltons that would yield a recognizable shift in the sedimentation. However, since it is known that lipid binding is involved, it may be that the change in buoyant density expected by the increase in molecular weight is compensated for by the lipid binding, which would explain the similarity of sedimentation. If the molecular-weight differences are indeed small, given the highly electronegative nature of the phospholipids and the electropositive charges of the binding peptides, it is conceivable that at least the gross electrophoretic variability could be produced by the binding of various numbers of small molecules of each class to the core enzyme. That would be consistent with the suggestion of Moss (1963) that the molecular heterogeneity may be due to charge differences rather than molecular-weight differences. 
We express our gratitude to the Biochemistry Department, to Mrs. M. H. Leber for the amino acid analysis and to Dr. L. Austin for the use of the spectrofluorimeter, all at Monash University.

\section{References}

Bligh, E. G. \& Dyer, W. J. (1959) Can. J. Biochem. Physiol. 37, 911-917

Etzler, M. E. \& Moog, F. (1968) Develop. Biol. 18, 515-535

Freeman, C. P. \& West, D. (1966) J. Lipid Res. 7, 324-327

Keiding, N. R. (1964) Clin. Sci. 26, 291-297

Lowry, O. H., Rosebrough, N. J., Farr, A. L. \& Randall, R. J. (1951) J. Biol. Chem. 193, 265-275

Margolis, J. \& Kenrick, K. G. (1968) Anal. Biochem. 25, 347-362

Martin, R. G. \& Ames, B. N. (1961) J. Biol. Chem. 236, 1372-1379

Moog, F., Vire, H. R. \& Grey, R. D. (1966) Biochim. Biophys. Acta 113, 336-349

Morton, R. K. (1954) Biochem. J. 57, 595-603

Moss, D. W. (1962) Proc. Ass. Clin. Biochem. 2, 5-6

Moss, D. W. (1963) Nature (London) 200, 1206-1207

Moss, D. W. \& King, E. T. (1962) Biochem. J. 84, 192-195
Moss, D. W., Eaton, R. H., Smith, J. K. \& Whitby, L. G. (1967) Biochem. J. 102, 53-57

Nichols, B. W. (1964) in New Biochemical Separations, (James, A. T. \& Morris, L. J., eds.), pp. 321-337, D. Van Nostrand and Co., London

Pearse, A. G. E. (1968) in Histochemistry: Theoretical and Applied, vol. 1, p. 511, J. and A. Churchill Ltd., London

Robson, E. B. \& Harris, H. (1966) Nature (London) 207, 1257-1259

Rosen, S. (1967) Ann. Intern. Med. 67, 183-203

Rosenberg, R. M., Crespi, H. L. \& Katz, J. J. (1969) Biochim. Biophys. Acta 175, 31-40

Steck, T. L. \& Fox, C. F. (1972) in Membrane Molecular Biology, (Fox, C. F. \& Keith, A. D., eds.), p. 42, Sinauer Associates Inc., Stanford, Conn.

Udenfriend, S., Stein, S., Böhlen, P., Dairman, W., Leimgruber, W. \& Weigele, M. (1972) Science 178, 871-972

Vaskovsky, V. E. \& Kostetsky, E. Y. (1966) J. Lipid Res. 9, 396

Wallach, D. F. H. \& Zahler, P. H. (1968) Biochim. Biophys. Acta 150, 186-193

Wilkinson, J. H. (1970) Isoenzymes, 2nd edn., p. 239, Chapman and Hall Ltd., London

Zahler, P. H. \& Wallach, D. F. H. (1967) Biochim. Biophys. Acta 135, 371-374 